\title{
Functions of PDE3 Isoforms in Cardiac Muscle
}

\author{
Matthew Movsesian 1,*, Faiyaz Ahmad ${ }^{2,+}$ and Emilio Hirsch 3 (i) \\ 1 Department of Internal Medicine/Division of Cardiovascular Medicine, University of Utah, \\ Salt Lake City, UT 841132, USA \\ 2 Vascular Biology and Hypertension Branch, Division of Cardiovascular Sciences, National Heart, Lung and \\ Blood Institute, Bethesda, MD 20892, USA; ahmadf@nhlbi.nih.gov \\ 3 Department of Molecular Biotechnology and Health Sciences, Center for Molecular Biotechnology, \\ University of Turin, 10126 Turin, Italy; emilio.hirsch@unito.it \\ * Correspondence: matthew.movsesian@hsc.utah.edu; Tel.: +1-801-582-1565 \\ † Beginning 18 February 2018: Sidra Medical Research Center, Doha, Qatar.
}

Received: 9 January 2018; Accepted: 1 February 2018; Published: 6 February 2018

\begin{abstract}
Isoforms in the PDE3 family of cyclic nucleotide phosphodiesterases have important roles in cyclic nucleotide-mediated signalling in cardiac myocytes. These enzymes are targeted by inhibitors used to increase contractility in patients with heart failure, with a combination of beneficial and adverse effects on clinical outcomes. This review covers relevant aspects of the molecular biology of the isoforms that have been identified in cardiac myocytes; the roles of these enzymes in modulating cAMP-mediated signalling and the processes mediated thereby; and the potential for targeting these enzymes to improve the profile of clinical responses.
\end{abstract}

Keywords: cyclic nucleotides; cAMP; cGMP; phosphodiesterase; PDE3; intracellular signalling; heart

\section{Introduction}

Cyclic nucleotide phosphodiesterases regulate intracellular signalling by hydrolysing cAMP and/or cGMP. Enzymes in the PDE3 family of phosphodiesterases are dual-specificity enzymes with high affinities for both cAMP and cGMP but much higher turnover rates for cAMP [1-3]. In cardiac muscle, these enzymes have been studied principally in the context of their role in regulating cAMP-mediated signalling, and this is the focus of our review.

Several isoforms of PDE3 are expressed in cardiac myocytes, and PDE3 inhibitors are used therapeutically to potentiate cAMP-mediated signalling in patients with heart failure. In the short term, these agents have the desired action of increasing myocardial contractility, but their long-term administration has been shown in several clinical trials to increase cardiovascular mortality [4-10]. This frustrating combination of beneficial and adverse effects of PDE3 inhibition presents a challenge that remains to be solved. Here we review the function of PDE3 isoforms in cardiac muscle and raise possibilities for targeting these isoforms so as to achieve more satisfying clinical outcomes.

\section{The PDE3 Family of Cyclic Nucleotide Phosphodiesterases}

Cyclic nucleotide phosphodiesterases comprise a superfamily of enzymes. As of now, more than 50 mammalian isoforms have been described and classified into eleven gene families (PDE1 through PDE11) defined on the basis of sensitivity to pharmacologic inhibitors, kinetic activity, and regulatory mechanisms [11]. PDE1, 2, 3, 10, and 11 hydrolyse both cAMP and cGMP; PDE4, PDE7, and PDE8 selectively hydrolyse cAMP; and PDE5, PDE6, and PDE9 selectively hydrolyse cGMP [11-13]. The $\mathrm{N}$-terminal regulatory regions of phosphodiesterases contain sequences involved in post-translational modifications and protein-protein interactions that target the enzymes to specific functional compartments. Transcription start sites and alternative splicing lead to the generation of multiple different isoforms of the same family. 
Enzymes in the PDE3 family are transcribed from two genes, PDE3A and PDE3B [14,15]. In the case of PDE3A, three isoforms (some prefer the term 'variants') are generated by transcription from alternative starts sites in the gene, yielding two mRNAs, as well as translation from alternative start sites in the smaller mRNA (Figure 1) [16]. As a result of these N-terminal 'deletions', the amino-acid sequences of these three isoforms differ only with respect to the lengths of their $\mathrm{N}$-terminal sequences. PDE3A1 (length: 996 amino acids; MW: 109,980), which is transcribed from an upstream start site and translated from the second AUG in the PDE3A open reading frame-a possibly misleading term in this case, as no isoform translated from the first AUG has been described-has an $\mathrm{N}$-terminal sequence containing hydrophobic loops that insert into intracellular membranes $[17,18]$, as well as three sites of phosphorylation that regulate protein-protein interactions [19-21]. PDE3A2 (length: 842 amino acids; MW: 93,600) is transcribed from a downstream site in exon 1 and translated from the fourth AUG in the PDE3A open reading frame; it lacks the most N-terminal phosphorylation site and the transmembrane hydrophobic loops of PDE3A1. PDE3A3 (length: 659 amino acids; MW: 73,720) is translated from the same mRNA as PDE3A2 and lacks all of the hydrophobic loops and the upstream phosphorylation sites. These three isoforms are essentially indistinguishable with respect to their basal catalytic activity and their sensitivity to catalytic site inhibitors [22]. At this time, only one isoform of PDE3B (length: 1112 amino acids; MW: 124,333) has been described [15]. Like PDE3A1, its $\mathrm{N}$-terminal sequence contains hydrophobic loops (six for PDE3B, as compared to four for PDE3A1) and phosphorylation sites, and its C-terminal sequence contains its catalytic region [23,24]. The sequence of the catalytic region of PDE3B is $>80 \%$ identical to that of PDE3A (both contain a 44-amino-acid insert absent from other phosphodiesterase families), and its catalytic activity and inhibitor sensitivity are similar to those of PDE3A; the remainder of the PDE3B sequence is $20-30 \%$ identical to that of PDE3A [3].

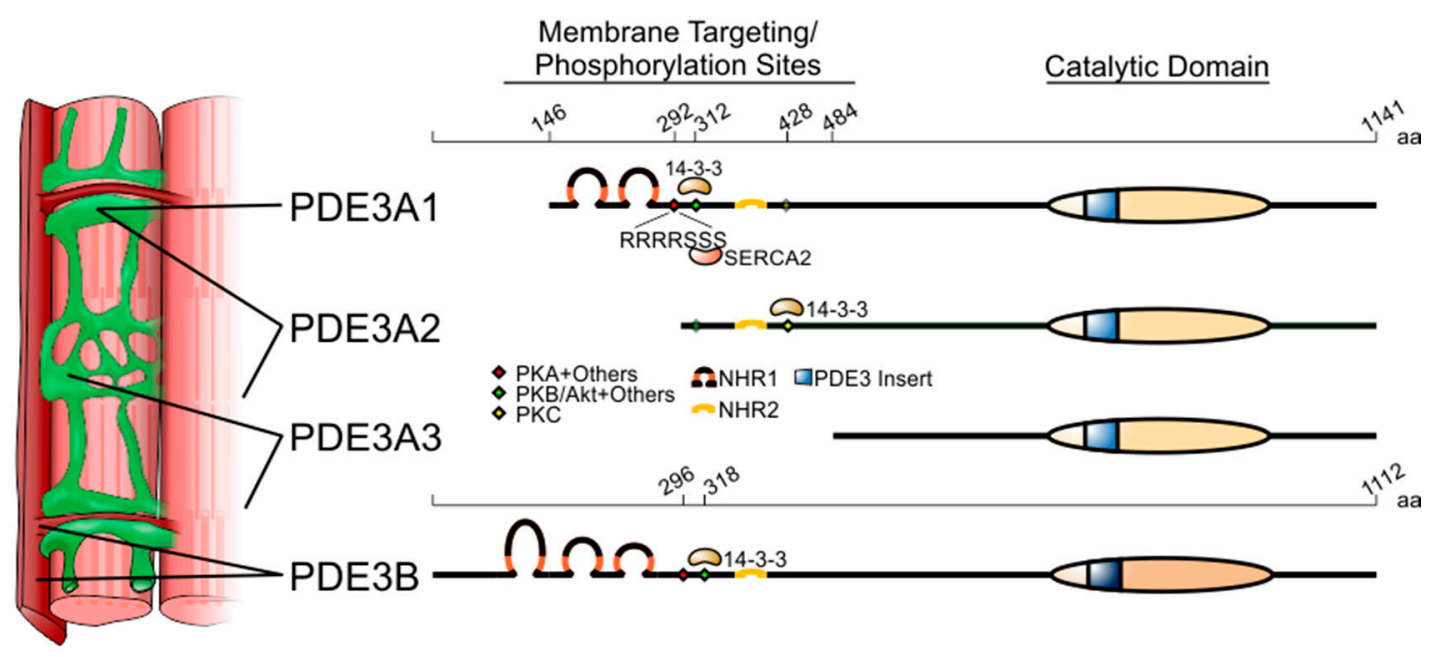

Figure 1. Structure and subcellular localisation of the PDE3 genes and their variants. Length in amino acids (aa) is provided at the top of the two PDE3 isoforms. PDE3A1 is translated from the second AUG codon of the open-reading frame found in the PDE3 mRNA. While the longest variant of PDE3A, PDE3A1, is mainly localised to the sarcoplasmic reticulum, PDE3A2 and PDE3A3 are found both in membranes and cytoplasm. PDE3B is mainly localised to plasma membrane invaginations known as $\mathrm{T}$ tubules. Coloured diamonds indicate phosphorylation sites. Selected PDE3-interacting proteins are listed where the precise binding sequences are known. Membrane-associated N-terminal hydrophobic regions 1 and 2 (NHR1 and 2) are depicted as loops. The catalytic domain, highly conserved between PDE3A and PDE3B, is indicated as a striped oval that includes the 44 -amino-acid insert characteristic of PDE3 isoforms. 


\section{Intracellular Localisation of PDE3A and PDE3B in Cardiac Myocytes and Their Protein-Protein Interactions}

Cyclic nucleotide-mediated signalling is highly compartmentalised in cardiac myocytes, and the roles of individual phosphodiesterases in regulating cAMP- and cGMP-mediated signalling depend upon their intracellular localisation. While PDE3A and PDE3B are both expressed in cardiac myocytes (PDE3A more abundantly [25]), their intracellular distributions are distinct, with PDE3A localised mainly to the sarcoplasmic reticulum and PDE3B to $\mathrm{T}$ tubules in proximity to mitochondria [26] (Figure 1). PDE3 activity is also associated with nuclear membranes in cardiac myocytes [27], though the specific isoforms have not been delineated. Furthermore, in subcellular preparations from cardiac muscle, PDE3A1 is recovered solely in microsomal fractions, while PDE3A2 and PDE3A3 are recovered in cytosolic as well as microsomal fractions [16]. This corresponds to studies in cells transfected with PDE3A1- and PDE3B-derived constructs that show that the N-terminal hydrophobic loops in these isoforms direct the insertion of these proteins into lipid membranes $[17,18]$.

\subsection{PDE3A}

The precise intracellular localisation of PDE3 isoforms depends upon their interactions with anchoring, scaffold, and adaptor proteins that recruit the enzyme to multiprotein signalling complexes [28-33]. Localised A-kinase anchoring proteins (AKAPs) tether protein kinase A (PKA) and other signalling proteins-adenylyl cyclases, phosphatases, Epacs, PDEs and other effector molecules— to 'signalosomes' that allow selective phosphorylation of individual PKA substrates [31-34].

PDE3 has long been known to be associated with the sarcoplasmic reticulum of cardiac myocytes [35,36]. Confocal microscopy studies more recently demonstrated co-localisation of PDE3A with SERCA2, AKAP18, phospholamban, and desmin in the Z-bands of cardiac myocytes $[37,38]$. PDE3A was found to be a constituent of a multiprotein complex in the sarcoplasmic reticulum containing AKAP18, phospholamban, and SERCA2 [38,39]. Addition of cAMP to microsomes from human heart results in the phosphorylation of phospholamban by endogenous PKA; this leads to a dissociation of phospholamban from SERCA2 and an increase in SERCA2 activity, and this effect is potentiated by PDE3 inhibition [38] (Figure 2). Although PDE3 and PDE4 have both been found to co-immunoprecipitate with AKAP-based signalosomes from human and mouse myocardium and modulate effects of cAMP on $L$-type $\mathrm{Ca}^{2+}$ channels, ryanodine-sensitive $\mathrm{Ca}^{2+}$ channels, and SERCA2 [40-43], only PDE3 inhibition potentiates the PKA-mediated phosphorylation of phospholamban and the consequent stimulation of SERCA2 activity [37]. The role of PDE3A in modulating these effects is the likely explanation for the inotropic actions of PDE3 inhibition.

Furthermore, while PDE3 isoforms regulate the phosphorylation of other proteins through the cAMP/PKA pathway, they are themselves substrates for protein kinases that modulate their catalytic activity and protein-protein interactions [19,21,44-47]. The incorporation of PDE3A into the SERCA2 complex is an example. In co-immunoprecipitation experiments, phosphorylation of endogenous PDE3A by PKA increases its interactions with SERCA2, caveolin-3, PKA regulatory subunit (PKARII), PP2A, and AKAP18 [38]. Studies with recombinant proteins showed that phosphorylation of PDE3A by PKA increased its co-immunoprecipitation with SERCA2a and AKAP18, suggesting that PDE3A interacts directly with both proteins in a phosphorylation-dependent manner [38]. Deletion of the N-terminal region of PDE3A1/PDE3A2 blocked PKA-induced phosphorylation of PDE3A and its interaction with recombinant SERCA2. Of particular interest is the sequence RRRRSSS (amino acids 288-294 of the open reading frame, which are found only in PDE3A1), which provides three serines that can be phosphorylated in vitro by different kinases under different conditions [19]. The introduction of serine-to-alanine substitutions at S292-4 identified this sequence as the principal site responsible for regulating the interactions of PDE3A1 with SERCA2 (Figure 1). 


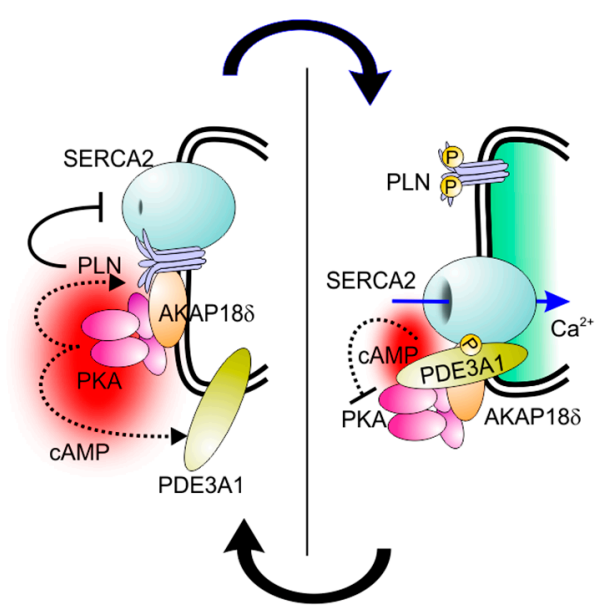

Figure 2. Control of SERCA2 activity by PDE3A. Left panel: Under resting conditions, phospholamban (PLN) binds to SERCA2, whose activity it inhibits, as well as AKAP18ס on the cytoplasmic surface of the sarcoplasmic reticulum (double black line). Upon $\beta$-adrenergic receptor-stimulated cAMP production, PKA associated with AKAP18 $\delta$ is activated and phosphorylates PLN (upper dotted line) and PDE3A1 (lower dotted line). This leads to the condition shown in the right panel, where phosphorylated PLN detaches from SERCA2 and loses its inhibitory action. As a consequence, SERCA2-dependent $\mathrm{Ca}^{2+}$ uptake into the lumen of the sarcoplasmic reticulum is stimulated (encircled by the double black line). At the same time, phosphorylated PDE3A1 binds to SERCA2 and increases its cAMP-hydrolytic activity, which limits the extent to which $\beta$-adrenergic receptor-mediated signalling amplifies intracellular $\mathrm{Ca}^{2+}$ cycling.

The absence of the S292-4 site from PDE3A2 and PDE3A3 establishes a PDE3A1-specific mechanism for recruitment of PDE3A to the SERCA2 complex. The protein-protein interactions of PDE3 isoforms are distinct in other ways as well, as has been described for the phosphorylation-dependent interactions of PDE3A1, PDE3A2, and PDE3B with 14-3-3 [20,21,48-50]. The common sequence of PDE3A1 and PDE3A2 includes two 14-3-3-binding sites: S428, a PKC site; and S312, a PKA/PKB (alternatively referred to Akt) site that resembles S318, a 14-3-3-binding site in PDE3B [48,49] (Figure 1). In vitro, PDE3A1 is preferentially phosphorylated by PKA at S312, whereas PDE3A2 is preferentially phosphorylated by PKC at S428; in preparations from human hearts, PDE3A1 is phosphorylated primarily at S312, while PDE3A2 is phosphorylated primarily at S428 [50]. Furthermore, in transfected HEK293 cells, the phosphorylation-dependent interactomes of PDE3A1 and PDE3A2 are distinct [50]: PDE3A1 interacts with the 5- $\mathrm{HT}_{4(\mathrm{~b})}$ receptor, for example, while PDE3A2, PDE3A3, and PDE3B do not [51]. These unique protein-protein interactions may provide opportunities for isoform-specific targeting of the protein-protein interactions of individual isoforms.

In cardiac myocytes, PDE3A is also part of a multiprotein complex containing the unconventional AKAP PI3K $\gamma$ [52]. While PI3K $\gamma$ directly binds the RII subunit of the PKA holoenzyme, how PDE3A contacts the complex is still unclear, though a likely intermediate is the PI3K $\gamma$ interactor p84/p87 [53]. Within this complex, PKA exerts a negative feedback regulation by phosphorylating and activating the different associated PDE isoforms, including PDE3A [39]. In line with the role of PDE3A (and PDE4A/B) in controlling SERCA2, loss of the scaffold function of PI3K $\gamma$ leads to cAMP elevation and PKA-mediated hyperphosphorylation of phospholamban and $L$-type $\mathrm{Ca}^{2+}$ channels [39,54] (Figure 3, left panel). In hearts lacking PI3K $\gamma$ and subjected to pressure overload, this effect causes cAMP elevation, contractile dysfunction, and increased mortality due to lethal arrhythmic events such as sustained ventricular tachycardia [39] (Figure 3, right panel). Interestingly, this abnormally increased cAMP accumulation appears to be selectively associated with signalling through $\beta$-adrenergic receptors localised to T tubules [55]. This would suggest that the PI3K $\gamma$ PKA/PDE complex is part of an 'insulating' system that blocks 'leakage' of cAMP from this compartment to 
the sarcoplasmic reticulum [39]. In heart failure, the expression of various elements of the PI3K $\gamma$ PKA/PDE3A-containing complex change their stoichiometric ratios, with reduced expression of $\mathrm{p} 84 / 87$ and coincident increased expression of PI3K $\gamma$. This causes a dysfunctional cAMP regulation potentially contributing to the increase in ventricular arrhythmias associated with heart failure [52].

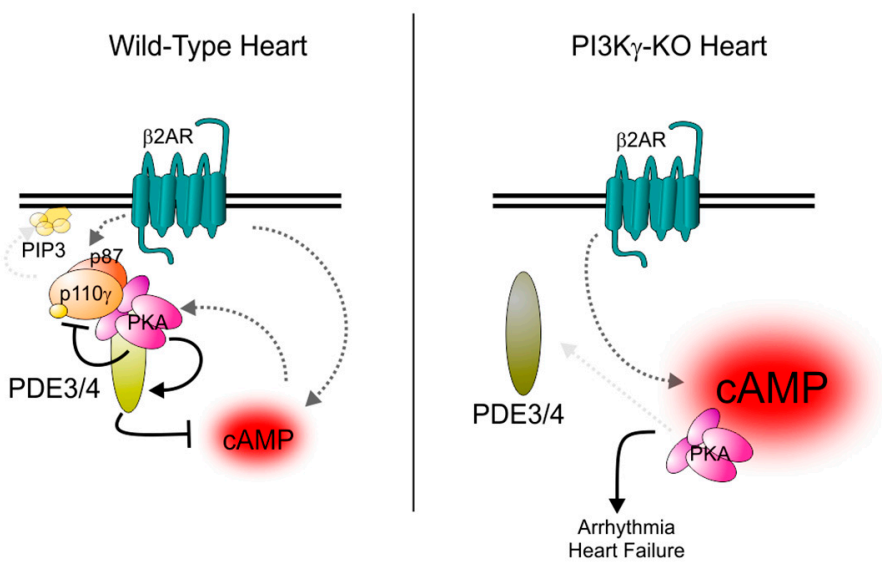

Figure 3. Regulation of PDE3 and PDE4 by the AKAP function of PI3K $\gamma$. Left panel: Regulation of $\mathrm{PI} 3 \mathrm{~K} \gamma$ and phosphodiesterase activity in healthy conditions. Upon stimulation of $\beta$-adrenergic receptors, cAMP production is promoted but simultaneously constrained by the activation of a negative feedback loop involving the scaffold function of PI3K $\gamma$ that directly binds the PKA holoenzyme containing the RII regulatory subunit as well as PDE3s and PDE4s. PKA activation leads to the phosphorylation of these phosphodiesterases and the consequent increase in their activity that, in turn, reduces cAMP levels. At the same time, PKA phosphorylates and inhibits PI3K $\gamma$, thus blocking the classical PI3K pathway signalling. Right panel: In the absence of PI3K $\gamma$, PKA is displaced from PDE3 and PDE4 enzymes and is unable to efficiently stimulate their activity. As a consequence, cAMP levels rise and cAMP diffuses to compartments that $\beta$-adrenergic receptor-mediated signalling does not usually affect.

\section{2. $P D E 3 B$}

In contrast to PDE3A, PDE3B is mainly located in caveolin-3-rich areas of the plasma membrane and, in cardiac myocytes, in the T tubules (Figure 1). This indicates that the two PDE3 genes are specifically involved in the regulation of spatially and functionally distinct pools of cAMP. In line with this view, while PDE3A is involved in the regulation of contractility, PDE3B appears more connected to the regulation of metabolism. PDE3B is also known to have a role in the liver, pancreatic $\beta$ cells, and in the brown and white adipose tissue where it is involved in the control of the anti-lipolytic effect of insulin, generally in contrast to $\beta$-adrenergic signalling [56,57]. In the heart, the specific inactivation of PDE3A causes alterations in basal cardiac contractility, while genetic ablation of PDE3B has no major impact on contractility but protects the myocardium from ischemic damage [26,37]. Interestingly, the protective effect of PDE3 inhibitors in ischemic heart preconditioning had been known for several years, but the precise nature of the PDE3 isoform only emerged with studies in knockout mice that excluded a role of PDE3A. The specific localisation of PDE3B in T tubules, and particularly both in dyads and in close proximity to mitochondria, suggests that this particular phosphodiesterase plays a role in modulating energy metabolism. Elevation in cAMP concentration in this location might mediate cardioprotective signals that improve mitochondrial function and energy supply during ischaemia/reperfusion, where mitochondrial $\mathrm{Ca}^{2+}$ overload and consequent mitochondrial permeability transition (MPT) pore opening, oxidative stress, and apoptosis contribute to injury [58]. In hearts lacking PDE3B, mitochondria are enriched in Bcl-2, produce lower amounts of reactive oxygen species, and show more numerous contacts with $\mathrm{T}$ tubules. In response to ischaemia, mitochondria from PDE3B-deficient cardiac myocytes are more resistant to $\mathrm{Ca}^{2+}$-induced opening of the MPT pore, 
and associate with caveolin-3-enriched membrane subfractions containing cardioprotective proteins. The recruitment of these cardioprotective proteins to these subfractions is PKA-dependent, and can be reproduced in wild-type mice by PDE3 inhibition [26].

The nature of the localization signal that keeps PDE3B in such spatially and functionally distinct cellular subdomains remains unknown. Various reports indicate that PDE3B can be recruited to different multiprotein complexes with distinct properties. In adipocytes, for example, treatment with insulin increases the phosphorylation of PDE3B associated with internal membranes, promoting its interactions with IRS-1 (insulin receptor substrate-1), IRS-2, PI3K p85 (p85-subunit of phosphoinositide 3-kinase), PKB (protein kinase B), HSP-90 (heat-shock protein 90), 14-3-3, and a $50 \mathrm{kD}$ protein $[46,47,56,59,60]$. Conversely, treatment with $\beta_{3}$-adrenergic receptor agonists increases the phosphorylation of PDE3B associated with caveolin-1 in caveolae, promoting interactions with $\beta_{3}$-adrenergic receptors, PKA-RII (PKA regulatory subunit), and hormone-sensitive lipase [46,61]. Whether these associations also occur in cardiac myocytes is not yet clear. PDE3B has been reported to weakly associate in a complex containing the unconventional AKAP PI3K $\gamma$, especially with overexpression in HEK293 cells [53,62]. Nonetheless, the significant effects on contractility and rhythm detected in mice lacking PI3K $\gamma$ indicate that the determinant of the cardiac phenotype is the ability of PI3K $\gamma$ to form more stable complexes with other phosphodiesterases, including PDE3A and PDE4A/B [39].

Of note, however, is that PDE3B can be phosphorylated not only by PKA but also by PKB, the main effector of the PI3K pathway. Although the weak interaction between PI3K $\gamma$ and PDE3B reported in the heart awaits further experimental confirmation, severe reduction of the G protein-coupled receptor-driven PI3K pathway by the concomitant loss of PI3K $\gamma$ and PI3K $\beta$ has been shown to lead to reduced PDE3B phosphorylation and activity in neurons [63]. Nonetheless, whereas the specific association of PI $3 \mathrm{~K} \gamma$ with $\beta$-adrenergic signalling in T tubules supports at least a spatial co-localisation of both PI3K and PDE3B [39,53], experiments in knockout mice indicate that PI3K $\gamma$ and PDE3B might be part of different functional complexes. On the other hand, the association of PI3K $\gamma$ with PKA triggers a negative feedback loop where PKA phosphorylates and inhibits PI3K $\gamma$ itself. Interestingly, loss of PDE3B in the heart leads to an unexpectedly strong elevation of cAMP [26], which likely remains spatially confined due to the normal activity of the other phosphodiesterases. Whether this elevated cAMP and PKA activity influences PI3K $\gamma$ catalytic activity and, indirectly, the PKB signalling axis is yet to be determined. As enhanced PI $3 \mathrm{~K} \gamma$ signalling is involved in the downregulation of $\beta$-adrenergic receptor density on the cell surface and, generally, in cardiac myocyte decompensation under stress, PDE3B inhibition could reduce a detrimental signal [64]. Inhibitors specifically distinguishing PDE3B from PDE3A are not currently available, but specific targeting of PDE3B may be therapeutically useful for ischaemia/reperfusion injury.

\section{Inotropic Actions of PDE3A Inhibition}

As discussed above, PDE3A is part of a multiprotein complex in the sarcoplasmic reticulum through which phospholamban phosphorylation and SERCA2 activity are regulated, and PDE3 inhibition potentiates the stimulatory effects of cAMP on SERCA2 activity in microsomes from cardiac muscle. These effects would be expected to increase contractility by increasing the amplitude of intracellular $\mathrm{Ca}^{2+}$ transients. Experiments in mice with selective ablation of PDE3A and PDE3B indicate that inotropic responses to PDE3 inhibition are attributable specifically to inhibition of PDE3A. Phospholamban phosphorylation, SERCA2 activity, intracellular $\mathrm{Ca}^{2+}$ cycling, and contractility are increased-and inotropic responses to PDE3 inhibition are eliminated-in Pde3a ${ }^{-1-}$ mice; none of these effects are observed in Pde $3 b^{-/-}$mice [37]. Furthermore, myocardial contractility in mice is reduced when PDE3A1 is overexpressed [65]. Total intracellular cAMP levels are higher in Pde $3 b^{-/-}$ mice than in $P d e 3 a^{-/-}$mice [26], indicating that this is not simply a 'mass effect' reflecting the higher abundance of PDE3A relative to PDE3B in cardiac myocytes but is instead due to the specific functional 
consequences of the intracellular localisation of these isoforms. (A unique role of PDE3B in mitigating reperfusion injury, discussed below, is further evidence along these lines [26].)

\section{Pro-Apoptotic Actions of PDE3A Inhibition}

PDE3 inhibition in rats and Pde3a ablation in mice lead to increases in the phosphorylation of cAMP response element-binding protein (CREB) and consequent increases in the expression of inducible cAMP early repressors (ICER's), promoting apoptosis [66,67]. Inhibition of PDE3, and especially of PDE3A, by milrinone might involve a phospho-CREB-induced increase in the expression of ICER, with consequent apoptosis and myocardial pathological remodelling. Conversely, there is evidence that increased PDE3A activity, achieved by overexpression in mice, reduces ICER expression, increases Bcl-2 expression, and protects cardiac myocytes against apoptosis [65]. In fact, specific overexpression of myocardial PDE3A1 in transgenic mice confers protection during ischaemia/reperfusion by decreasing cAMP signalling and phosphorylation of CREB, resulting in decreased expression of ICER and reduced apoptosis [65]. PDE3 activity is associated with nuclear membranes in cardiac myocytes [27], and it is possible that the activity localised to this region is responsible for these pro-apoptotic changes in gene expression.

\section{Pro-Hypertrophic Actions of PDE3A Inhibition}

PDE3 inhibition has pro-hypertrophic actions in neonatal rat ventricular myocytes [68]. These effects are essentially reproduced by expression of a dominant-negative form of PDE3A2 induced by a single amino acid substitution in the C-terminal region that renders the protein catalytically inactive but otherwise intact [68]. This dominant-negative construct presumably functions as a competitive inhibitor of the localising protein-protein interactions of the native protein to disrupt its intracellular targeting; this is further evidence that the intracellular targeting of PDE3 isoforms is as important as their catalytic activity. The antihypertrophic effect is especially interesting in view of the description of a set of genetically unrelated missense mutations within a five-amino-acid sequence in PDE3A that increase catalytic activity and lead to a syndrome of brachydactyly and hypertension $[69,70]$. The hypertension is likely attributable to increased cGMP hydrolysis in vascular smooth muscle; the resulting decrease in intracellular cGMP content would lead to a combination of vasoconstriction and vessel wall hyperplasia. Despite the severe hypertension, however, patients with this syndrome have strikingly low levels of cardiac hypertrophy [71]. This suggests that an increase in PDE3A activity in cardiac myocytes may in fact be antihypertrophic, consistent with the benefits of PDE3A1 overexpression with respect to pathologic remodelling in animal models discussed above [65].

\section{Clinical Experience with PDE3 Inhibition in the Treatment of Heart Disease}

With respect to cardiac disease, PDE3 has been of interest principally as a target for increasing contractility in patients with heart failure, a condition in which decreases in $\beta$-adrenergic receptor density and increases in G $\alpha$ i and $\beta$-adrenergic receptor kinase activity in cardiac myocytes attenuate cAMP generation lead to decreases in cAMP content, protein phosphorylation and the amplitude of intracellular $\mathrm{Ca}^{2+}$ transients [72-81]. Inhibiting PDE3 has the effect of compensating to some extent for these changes by blocking cAMP hydrolysis and potentiating cAMP-mediated signalling, leading to an increase in myocardial contractility [82-88].

This short-term benefit, unfortunately, is outweighed by an increase in mortality from sudden cardiac death of $\sim 3 \%$ per year when these drugs are administered chronically [4-10]. The explanation for this increase is unclear (though it seems restricted to patients in whom PDE3 inhibition is used to treat contractile failure; no increase in mortality has been seen when the PDE3 inhibitor cilostazol has been used to treat intermittent claudication [89]). Overexpression of SERCA2 in animal models of ischaemia/reperfusion and chronic heart failure is anti-arrhythmic [90,91]. On the other hand, an increase in the phosphorylation of $L$-type and ryanodine-sensitive $\mathrm{Ca}^{2+}$ channels may be pro-arrhythmic [40-43]. It seems more probable, however, based on the fact that short-term 
administration of these agents is well tolerated, that mechanisms other than direct pro-arrhythmic actions are involved, and that the pro-apoptotic and pro-hypertrophic effects of PDE3 inhibition described above induce pathologic changes in the myocardium that increase the proclivity toward malignant arrhythmias.

\section{Selective Targeting of PDE3 Isoforms}

The fact that PDE3A and PDE3B have different roles in cardiac myocytes, with PDE3A controlling the pathways responsible for inotropic effects, raises the possibility that targeting PDE3A selectively —or, perhaps even better, selectively targeting one of its three known variants-might improve contractility without increasing sudden cardiac death (as noted above, PDE3A1 is restricted in its distribution to intracellular membranes, so that its inhibition may be less likely to elicit pro-apoptotic and pro-arrhythmic actions [16]). The catalytic activities, substrate affinities, and inhibitor sensitivities of PDE3A1, PDE3A2, and PDE3A3 are identical, making it impossible to selectively target the active sites of individual PDE3A variants [22]. The similarity of the PDE3B active site to the PDE3A active site suggested that selectivity between these two proteins would also prove challenging. Recently, however, investigators described a compound with a tenfold higher affinity for PDE3A relative to PDE3B [92], so this supposition needs to be reconsidered. It is not obvious how targeting all PDE3A isoforms without targeting PDE3B would confer a therapeutic advantage, however. To our knowledge, no compound with a significantly higher affinity for PDE3B relative to PDE3A has been reported.

Another possibility is that of targeting individual isoforms not through their active sites but through the protein-protein interactions by which they are localised intracellularly. As noted above, PDE3A1 and PDE3A2 are recruited, by phosphorylation within their N-terminal sequences, to a SERCA2/phospholamban/AKAP/PKA complex in the sarcoplasmic reticulum [37,93]. As a result of this recruitment, PDE3 inhibition has a particularly pronounced effect in potentiating phospholamban phosphorylation and increasing SERCA2 activity, leading to an increase in SERCA2 activity and intracellular $\mathrm{Ca}^{2+}$ [38]. Experiments using recombinant proteins have demonstrated direct interactions of PDE3A1 and PDE3A2 with both SERCA2 and AKAP18, and have shown that the interaction of PDE3A1 with SERCA2 is dependent upon its phosphorylation at serine 293, a site within its unique $\mathrm{N}$-terminal extension (Figure 1) [38]. These findings indicate that the protein-protein interactions of the PDE3A isoforms responsible for inotropic responses are highly individualised, opening an avenue to isoform-selective targeting with a high degree of precision. In fact, this approach to isoform-selective targeting-displacing PDE3A from specific multiprotein complexes-has the added benefit of compartment selectivity, which is likely its most important advantage. Conventional PDE3 inhibitors target the enzyme regardless of its intracellular location; this can raise cAMP content globally within the cell, resulting in a combination of pro-apoptotic, pro-hypertrophic, and inotropic [66-68]. Blocking the protein-protein interactions that integrate PDE3A into SERCA2 complexes could lead to a selective increase in cAMP content in the vicinity of phospholamban and SERCA2 so as to amplify intracellular $\mathrm{Ca}^{2+}$ cycling and increase contractility without the deleterious pro-arrhythmic, pro-apoptotic, and pro-hypertrophic consequences (Figure 4).

On the other hand, the protein-protein interactions that localise PDE3B intracellularly may be targets through which the cardioprotective effects of PDE3B ablation can be elicited without the adverse pro-hypertrophic and pro-arrhythmic consequences of PDE3A inhibition. The feasibility of this approach has been demonstrated in experiments using peptides that block the protein-protein interactions of cyclic nucleotide phosphodiesterases. In one example, peptide-array scanning identified a cell-permeant peptide based on a sequence in the N-terminus of PDE3B through which it is incorporated into an Epac1/PI3K $\gamma$ complex in vascular endothelial cells. This peptide has been shown to block the integration of PDE3B into this complex, increasing the activation of Epac1 by cAMP and promoting intracellular tubule formation, cell adhesion, and cell spreading [94]. 

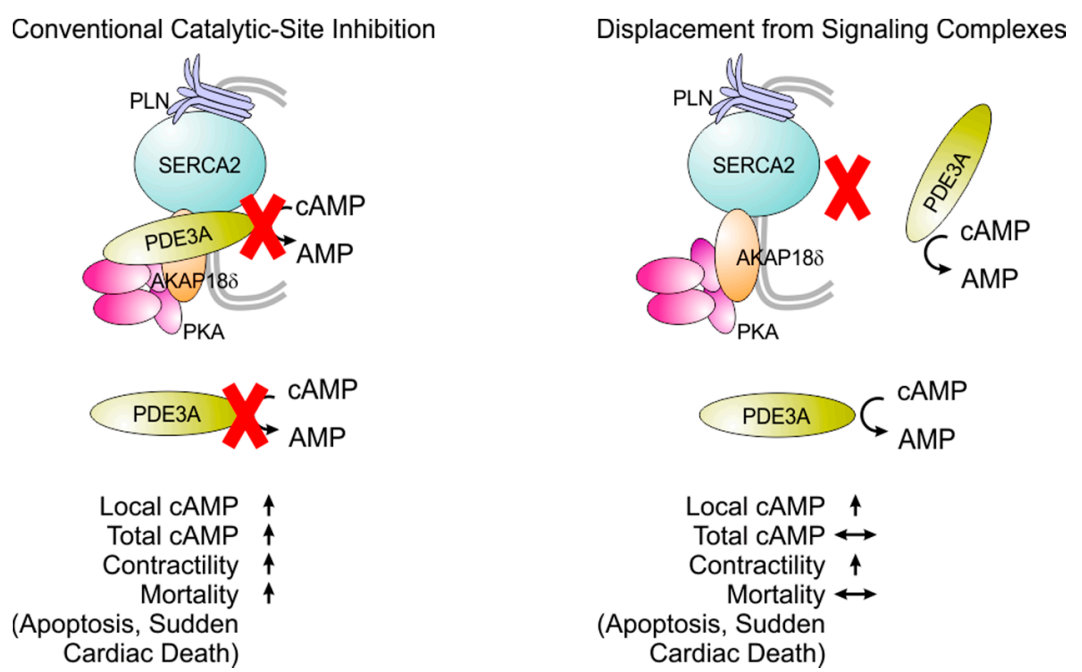

Figure 4. Targeting PDE3A through protein-protein interactions. Conventional PDE3 inhibition activates cAMP-mediated signalling in multiple intracellular compartments, leading possibly to a combination of beneficial and adverse effects. Blocking the protein-protein interactions through which PDE3A is integrated into the SERCA2 complex may stimulate intracellular $\mathrm{Ca}^{2+}$ cycling without the adverse effects.

\section{Conclusions}

Several isoforms in the PDE3 family are expressed in cardiac myocytes, where they have important roles regulating signalling pathways involved in inotropic, pro-apoptotic, and pro-hypertrophic responses. Inhibition of myocardial PDE3 activity is an established therapeutic strategy for increasing contractility in patients with heart failure, but an increase in sudden cardiac death in patients treated chronically with existing PDE3 inhibitors has limited the benefits. Targeting individual PDE3A isoforms in specific intracellular targets could potentially yield inotropic responses without this adverse effect, while targeting PDE3B could have beneficial actions in ischaemia/reperfusion injury. Recent discoveries open the possibility of selectively inhibiting PDE3A or PDE3B at their catalytic sites or, probably more interestingly, of targeting their unique protein-protein interactions to yield compartment-specific effects on intracellular signalling. Time will tell.

Acknowledgments: Matthew Movsesian was supported by Medical Research Funds from the United States Department of Veterans Affairs and a Univa grant from the Eunice Kennedy Shriver National Institute of Child Health and Human Development (R37HD014939; Laurinda Jaffe, Principal Investigator). Faiyaz Ahmad was supported by the NHLBI Intramural Research Program, National Institutes of Health, United States of America. Emilio Hirsch was supported by the grant Telethon GGP14106.

Author Contributions: All three authors wrote the paper. The comments expressed here are those of the authors, and do not reflect official positions of the National Heart, Lung and Blood Institute or National Institutes of Health.

Conflicts of Interest: Matthew Movsesian is the author of patents EP1430140, USPTO 8722866, USPTO 9513288 and USPTO 9513289 issued to the United States Department of Veterans Affairs relating to the targeting of PDE3 isoforms. 


\section{Abbreviations}

$\begin{array}{ll}\text { aa } & \text { amino acid } \\ \text { AKAP } & \text { A-kinase-anchoring protein } \\ \beta_{2} \text {-AR } & \beta_{2} \text {-adrenergic receptor } \\ \text { cAMP } & \text { Cyclic adenosine monophosphate } \\ \text { IRS } & \text { Insulin-receptor substrate } \\ \text { NHR } & \text { N-terminal hydrophobic region } \\ \text { PLN } & \text { Phospholamban } \\ \text { PKA } & \text { cAMP-dependent protein kinase } \\ \text { PKA-RII } & \text { cAMP-dependent protein kinase regulatory subunit II } \\ \text { PKB (AKT) } & \text { Protein kinase B } \\ \text { PKC } & \text { Protein kinase C } \\ \text { PI3K } \gamma & \text { Phosphoinositide 3-kinase } \gamma \\ \text { PIP3 } & \text { Phosphatidylinositol (3,4,5)-triphosphate } \\ \text { p110 } \gamma & \text { Phosphoinositide 3-kinase } \gamma(\text { PI3K } \gamma) \text { catalytic subunit } \\ \text { p87 } & \text { PI3K } \gamma \text { regulatory subunit (also known as p87PIKAP p87-PI3K adapter protein) } \\ \text { SERCA2 } & \text { Sarcoplasmic/endoplasmic reticulum calcium ATPase-2 }\end{array}$

\section{References}

1. Grant, P.G.; Colman, R.W. Purification and characterization of a human platelet cyclic nucleotide phosphodiesterase. Biochemistry 1984, 23, 1801-1807. [CrossRef] [PubMed]

2. Boyes, S.; Loten, E.G. Purification of an insulin-sensitive cyclic AMP phosphodiesterase from rat liver. Eur. J. Biochem. 1988, 174, 303-309. [CrossRef] [PubMed]

3. Degerman, E.; Belfrage, P.; Manganiello, V.C. Structure, localization, and regulation of cGMP-inhibited phosphodiesterase (PDE3). J. Biol. Chem. 1997, 272, 6823-6826. [CrossRef] [PubMed]

4. DiBianco, R.; Shabetai, R.; Kostuk, W.; Moran, J.; Schlant, R.C.; Wright, R. A comparison of oral milrinone, digoxin, and their combination in the treatment of patients with chronic heart failure. N. Engl. J. Med. 1989, 320, 677-683. [CrossRef] [PubMed]

5. Uretsky, B.F.; Jessup, M.; Konstam, M.A.; Dec, G.W.; Leier, C.V.; Benotti, J.; Murali, S.; Herrmann, H.C.; Sandberg, J.A. Multicenter trial of oral enoximone in patients with moderate to moderately severe congestive heart failure. Lack of benefit compared with placebo. Enoximone Multicenter Trial Group. Circulation 1990, 82, 774-780. [CrossRef] [PubMed]

6. Narahara, K.A. Oral enoximone therapy in chronic heart failure: A placebo-controlled randomized trial. The Western Enoximone Study Group. Am. Heart J. 1991, 121, 1471-1479. [CrossRef]

7. Packer, M.; Carver, J.R.; Rodeheffer, R.J.; Ivanhoe, R.J.; DiBianco, R.; Zeldis, S.M.; Hendrix, G.H.; Bommer, W.J.; Elkayam, U.; Kukin, M.L.; et al. Effect of oral milrinone on mortality in severe chronic heart failure. The PROMISE Study Research Group. N. Engl. J. Med. 1991, 325, 1468-1475. [CrossRef] [PubMed]

8. Packer, M.; Narahara, K.A.; Elkayam, U.; Sullivan, J.M.; Pearle, D.L.; Massie, B.M.; Creager, M.A. Double-blind, placebo-controlled study of the efficacy of flosequinan in patients with chronic heart failure. Principal Investigators of the REFLECT Study. J. Am. Coll. Cardiol. 1993, 22, 65-72. [CrossRef]

9. Cohn, J.N.; Goldstein, S.O.; Greenberg, B.H.; Lorell, B.H.; Bourge, R.C.; Jaski, B.E.; Gottlieb, S.O.; McGrew, F., 3rd; DeMets, D.L.; White, B.G. A dose-dependent increase in mortality with vesnarinone among patients with severe heart failure. Vesnarinone Trial Investigators. N. Engl. J. Med. 1998, 339, 1810-1816. [CrossRef] [PubMed]

10. Amsallem, E.; Kasparian, C.; Haddour, G.; Boissel, J.P.; Nony, P. Phosphodiesterase III inhibitors for heart failure. Cochrane Database Syst. Rev. 2005. [CrossRef] [PubMed]

11. Maurice, D.H.; Ke, H.; Ahmad, F.; Wang, Y.; Chung, J.; Manganiello, V.C. Advances in targeting cyclic nucleotide phosphodiesterases. Nat. Rev. Drug Discov. 2014, 13, 290-314. [CrossRef] [PubMed]

12. Keravis, T.; Lugnier, C. Cyclic nucleotide phosphodiesterases (PDE) and peptide motifs. Curr. Pharm. Des. 2010, 16, 1114-1125. [CrossRef] [PubMed]

13. Francis, S.H.; Blount, M.A.; Corbin, J.D. Mammalian cyclic nucleotide phosphodiesterases: Molecular mechanisms and physiological functions. Physiol. Rev. 2011, 91, 651-690. [CrossRef] [PubMed] 
14. Meacci, E.; Taira, M.; Moos, M., Jr.; Smith, C.J.; Movsesian, M.A.; Degerman, E.; Belfrage, P.; Manganiello, V. Molecular cloning and expression of human myocardial cGMP-inhibited cAMP phosphodiesterase. Proc. Natl. Acad. Sci. USA 1992, 89, 3721-3725. [CrossRef] [PubMed]

15. Miki, T.; Taira, M.; Hockman, S.; Shimada, F.; Lieman, J.; Napolitano, M.; Ward, D.; Taira, M.; Makino, H.; Manganiello, V.C. Characterization of the cDNA and gene encoding human PDE3B, the cGIP1 isoform of the human cyclic GMP-inhibited cyclic nucleotide phosphodiesterase family. Genomics 1996, 36, 476-485. [CrossRef] [PubMed]

16. Wechsler, J.; Choi, Y.H.; Krall, J.; Ahmad, F.; Manganiello, V.C.; Movsesian, M.A. Isoforms of cyclic nucleotide phosphodiesterase PDE3A in cardiac myocytes. J. Biol. Chem. 2002, 277, 38072-38078. [CrossRef] [PubMed]

17. Kenan, Y.; Murata, T.; Shakur, Y.; Degerman, E.; Manganiello, V.C. Functions of the N-terminal region of cyclic nucleotide phosphodiesterase 3 (PDE 3) isoforms. J. Biol. Chem. 2000, 275, 12331-12338. [CrossRef] [PubMed]

18. Shakur, Y.; Takeda, K.; Kenan, Y.; Yu, Z.X.; Rena, G.; Brandt, D.; Houslay, M.D.; Degerman, E.; Ferrans, V.J.; Manganiello, V.C. Membrane localization of cyclic nucleotide phosphodiesterase 3 (PDE3). Two N-terminal domains are required for the efficient targeting to, and association of, PDE3 with endoplasmic reticulum. J. Biol. Chem. 2000, 275, 38749-38761. [CrossRef] [PubMed]

19. Han, S.J.; Vaccari, S.; Nedachi, T.; Andersen, C.B.; Kovacina, K.S.; Roth, R.A.; Conti, M. Protein kinase B/Akt phosphorylation of PDE3A and its role in mammalian oocyte maturation. EMBO J. 2006, 25, 5716-5725. [CrossRef] [PubMed]

20. Pozuelo Rubio, M.; Campbell, D.G.; Morrice, N.A.; Mackintosh, C. Phosphodiesterase 3A binds to 14-3-3 proteins in response to PMA-induced phosphorylation of Ser428. Biochem. J. 2005, 392, 163-172. [CrossRef] [PubMed]

21. Hunter, R.W.; Mackintosh, C.; Hers, I. Protein kinase C-mediated phosphorylation and activation of PDE3A regulate cAMP levels in human platelets. J. Biol. Chem. 2009, 284, 12339-12348. [CrossRef] [PubMed]

22. Hambleton, R.; Krall, J.; Tikishvili, E.; Honeggar, M.; Ahmad, F.; Manganiello, V.C.; Movsesian, M.A. Isoforms of cyclic nucleotide phosphodiesterase PDE3 and their contribution to cAMP hydrolytic activity in subcellular fractions of human myocardium. J. Biol. Chem. 2005, 280, 39168-39174. [CrossRef] [PubMed]

23. Leroy, M.J.; Degerman, E.; Taira, M.; Murata, T.; Wang, L.H.; Movsesian, M.A.; Meacci, E.; Manganiello, V.C. Characterization of two recombinant PDE3 (cGMP-inhibited cyclic nucleotide phosphodiesterase) isoforms, RcGIP1 and HcGIP2, expressed in NIH 3006 murine fibroblasts and Sf9 insect cells. Biochemistry 1996, 35, 10194-10202. [CrossRef] [PubMed]

24. Taira, M.; Hockman, S.C.; Calvo, J.C.; Taira, M.; Belfrage, P.; Manganiello, V.C. Molecular cloning of the rat adipocyte hormone-sensitive cyclic GMP-inhibited cyclic nucleotide phosphodiesterase. J. Biol. Chem. 1993, 268, 18573-18579. [PubMed]

25. Reinhardt, R.R.; Chin, E.; Zhou, J.; Taira, M.; Murata, T.; Manganiello, V.C.; Bondy, C.A. Distinctive anatomical patterns of gene expression for CGMP-inhibited cyclic nucleotide phosphodiesterases. J. Clin. Investig. 1995, 95, 1528-1538. [CrossRef] [PubMed]

26. Chung, Y.W.; Lagranha, C.; Chen, Y.; Sun, J.; Tong, G.; Hockman, S.C.; Ahmad, F.; Esfahani, S.G.; Bae, D.H.; Polidovitch, N.; et al. Targeted disruption of PDE3B, but not PDE3A, protects murine heart from ischemia/reperfusion injury. Proc. Natl. Acad. Sci. USA 2015, 112, E2253-E2262. [CrossRef] [PubMed]

27. Lugnier, C.; Keravis, T.; Le Bec, A.; Pauvert, O.; Proteau, S.; Rousseau, E. Characterization of cyclic nucleotide phosphodiesterase isoforms associated to isolated cardiac nuclei. Biochim. Biophys. Acta 1999, 1472, 431-446. [CrossRef]

28. Zaccolo, M. cAMP signal transduction in the heart: Understanding spatial control for the development of novel therapeutic strategies. Br. J. Pharmacol. 2009, 158, 50-60. [CrossRef] [PubMed]

29. Houslay, M.D. Underpinning compartmentalised cAMP signalling through targeted cAMP breakdown. Trends Biochem. Sci. 2010, 35, 91-100. [CrossRef] [PubMed]

30. Raymond, D.R.; Wilson, L.S.; Carter, R.L.; Maurice, D.H. Numerous distinct PKA-, or EPAC-based, signalling complexes allow selective phosphodiesterase 3 and phosphodiesterase 4 coordination of cell adhesion. Cell Signal. 2007, 19, 2507-2518. [CrossRef] [PubMed]

31. Scott, J.D.; Santana, L.F. A-kinase anchoring proteins: Getting to the heart of the matter. Circulation 2010, 121, 1264-1271. [CrossRef] [PubMed] 
32. Stangherlin, A.; Zaccolo, M. Local termination of $3^{\prime}-5^{\prime}$-cyclic adenosine monophosphate signals: The role of A kinase anchoring protein-tethered phosphodiesterases. J. Cardiovasc. Pharmacol. 2011, 58, 345-353. [CrossRef] [PubMed]

33. Kritzer, M.D.; Li, J.; Dodge-Kafka, K.; Kapiloff, M.S. AKAPs: The architectural underpinnings of local cAMP signaling. J. Mol. Cell. Cardiol. 2012, 52, 351-358. [CrossRef] [PubMed]

34. Perino, A.; Ghigo, A.; Scott, J.D.; Hirsch, E. Anchoring proteins as regulators of signaling pathways. Circ. Res. 2012, 111, 482-492. [CrossRef] [PubMed]

35. Movsesian, M.A.; Smith, C.J.; Krall, J.; Bristow, M.R.; Manganiello, V.C. Sarcoplasmic reticulum-associated cyclic adenosine $5^{\prime}$-monophosphate phosphodiesterase activity in normal and failing human hearts. J. Clin. Investig. 1991, 88, 15-19. [CrossRef] [PubMed]

36. Lugnier, C.; Muller, B.; Le Bec, A.; Beaudry, C.; Rousseau, E. Characterization of indolidan- and rolipram-sensitive cyclic nucleotide phosphodiesterases in canine and human cardiac microsomal fractions. J. Pharmacol. Exp. Ther. 1993, 265, 1142-1151. [PubMed]

37. Beca, S.; Ahmad, F.; Shen, W.; Liu, J.; Makary, S.; Polidovitch, N.; Sun, J.; Hockman, S.; Chung, Y.W.; Movsesian, M.; et al. Phosphodiesterase type 3A regulates basal myocardial contractility through interacting with sarcoplasmic reticulum calcium ATPase type 2a signaling complexes in mouse heart. Circ. Res. 2013, 112, 289-297. [CrossRef] [PubMed]

38. Ahmad, F.; Shen, W.; Vandeput, F.; Szabo-Fresnais, N.; Krall, J.; Degerman, E.; Goetz, F.; Klussmann, E.; Movsesian, M.; Manganiello, V. Regulation of sarcoplasmic reticulum $\mathrm{Ca}^{2+}$ ATPase 2 (SERCA2) activity by phosphodiesterase 3A (PDE3A) in human myocardium: Phosphorylation-dependent interaction of PDE3A1 with SERCA2. J. Biol. Chem. 2015, 290, 6763-6776. [CrossRef] [PubMed]

39. Ghigo, A.; Laffargue, M.; Li, M.; Hirsch, E. PI3K and Calcium Signaling in Cardiovascular Disease. Circ. Res. 2017, 121, 282-292. [CrossRef] [PubMed]

40. Richter, W.; Xie, M.; Scheitrum, C.; Krall, J.; Movsesian, M.A.; Conti, M. Conserved expression and functions of PDE4 in rodent and human heart. Basic Res. Cardiol. 2011, 106, 249-262. [CrossRef] [PubMed]

41. Lehnart, S.E.; Wehrens, X.H.; Reiken, S.; Warrier, S.; Belevych, A.E.; Harvey, R.D.; Richter, W.; Jin, S.L.; Conti, M.; Marks, A.R. Phosphodiesterase 4D deficiency in the ryanodine-receptor complex promotes heart failure and arrhythmias. Cell 2005, 123, 25-35. [CrossRef] [PubMed]

42. Kerfant, B.G.; Zhao, D.; Lorenzen-Schmidt, I.; Wilson, L.S.; Cai, S.; Chen, S.R.; Maurice, D.H.; Backx, P.H. PI3Kgamma is required for PDE4, not PDE3, activity in subcellular microdomains containing the sarcoplasmic reticular calcium ATPase in cardiomyocytes. Circ. Res. 2007, 101, 400-408. [CrossRef] [PubMed]

43. Leroy, J.; Richter, W.; Mika, D.; Castro, L.R.; Abi-Gerges, A.; Xie, M.; Scheitrum, C.; Lefebvre, F.; Schittl, J.; Mateo, P.; et al. Phosphodiesterase 4B in the cardiac L-type $\mathrm{Ca}(2)(+)$ channel complex regulates $\mathrm{Ca}(2)(+)$ current and protects against ventricular arrhythmias in mice. J. Clin. Investig. 2011, 121, 2651-2661. [CrossRef] [PubMed]

44. Macphee, C.H.; Reifsnyder, D.H.; Moore, T.A.; Lerea, K.M.; Beavo, J.A. Phosphorylation results in activation of a cAMP phosphodiesterase in human platelets. J. Biol. Chem. 1988, 263, 10353-10358. [PubMed]

45. Grant, P.G.; Mannarino, A.F.; Colman, R.W. cAMP-mediated phosphorylation of the low-Km cAMP phosphodiesterase markedly stimulates its catalytic activity. Proc. Natl. Acad. Sci. USA 1988, 85, 9071-9075. [CrossRef] [PubMed]

46. Ahmad, F.; Lindh, R.; Tang, Y.; Ruishalme, I.; Ost, A.; Sahachartsiri, B.; Stralfors, P.; Degerman, E.; Manganiello, V.C. Differential regulation of adipocyte PDE3B in distinct membrane compartments by insulin and the beta3-adrenergic receptor agonist CL316243: Effects of caveolin-1 knockdown on formation/maintenance of macromolecular signalling complexes. Biochem. J. 2009, 424, 399-410. [CrossRef] [PubMed]

47. Ahmad, F.; Lindh, R.; Tang, Y.; Weston, M.; Degerman, E.; Manganiello, V.C. Insulin-induced formation of macromolecular complexes involved in activation of cyclic nucleotide phosphodiesterase 3B (PDE3B) and its interaction with PKB. Biochem. J. 2007, 404, 257-268. [CrossRef] [PubMed]

48. Onuma, H.; Osawa, H.; Yamada, K.; Ogura, T.; Tanabe, F.; Granner, D.K.; Makino, H. Identification of the insulin-regulated interaction of phosphodiesterase 3B with 14-3-3 beta protein. Diabetes 2002, 51, 3362-3367. [CrossRef] [PubMed] 
49. Palmer, D.; Jimmo, S.L.; Raymond, D.R.; Wilson, L.S.; Carter, R.L.; Maurice, D.H. Protein kinase A phosphorylation of human phosphodiesterase 3B promotes 14-3-3 protein binding and inhibits phosphatase-catalyzed inactivation. J. Biol. Chem. 2007, 282, 9411-9419. [CrossRef] [PubMed]

50. Vandeput, F.; Szabo-Fresnais, N.; Ahmad, F.; Kho, C.; Lee, A.; Krall, J.; Dunlop, A.; Hazel, M.W.; Wohlschlegel, J.A.; Hajjar, R.J.; et al. Selective regulation of cyclic nucleotide phosphodiesterase PDE3A isoforms. Proc. Natl. Acad. Sci. USA 2013, 110, 19778-19783. [CrossRef] [PubMed]

51. Weninger, S.; Van Craenenbroeck, K.; Cameron, R.T.; Vandeput, F.; Movsesian, M.A.; Baillie, G.S.; Lefebvre, R.A. Phosphodiesterase 4 interacts with the 5-HT4(b) receptor to regulate cAMP signaling. Cell Signal. 2014, 26, 2573-2582. [CrossRef] [PubMed]

52. Ghigo, A.; Perino, A.; Mehel, H.; Zahradnikova, A., Jr.; Morello, F.; Leroy, J.; Nikolaev, V.O.; Damilano, F.; Cimino, J.; De Luca, E.; et al. Phosphoinositide 3-kinase gamma protects against catecholamine-induced ventricular arrhythmia through protein kinase A-mediated regulation of distinct phosphodiesterases. Circulation 2012, 126, 2073-2083. [CrossRef] [PubMed]

53. Perino, A.; Ghigo, A.; Ferrero, E.; Morello, F.; Santulli, G.; Baillie, G.S.; Damilano, F.; Dunlop, A.J.; Pawson, C.; Walser, R.; et al. Integrating cardiac PIP3 and cAMP signaling through a PKA anchoring function of p110gamma. Mol. Cell 2011, 42, 84-95. [CrossRef] [PubMed]

54. Marcantoni, A.; Levi, R.C.; Gallo, M.P.; Hirsch, E.; Alloatti, G. Phosphoinositide 3-kinasegamma (PI3Kgamma) controls L-type calcium current (ICa,L) through its positive modulation of type-3 phosphodiesterase (PDE3). J. Cell. Physiol. 2006, 206, 329-336. [CrossRef] [PubMed]

55. Nikolaev, V.O.; Moshkov, A.; Lyon, A.R.; Miragoli, M.; Novak, P.; Paur, H.; Lohse, M.J.; Korchev, Y.E.; Harding, S.E.; Gorelik, J. Beta2-adrenergic receptor redistribution in heart failure changes cAMP compartmentation. Science 2010, 327, 1653-1657. [CrossRef] [PubMed]

56. Rondinone, C.M.; Carvalho, E.; Rahn, T.; Manganiello, V.C.; Degerman, E.; Smith, U.P. Phosphorylation of PDE3B by phosphatidylinositol 3-kinase associated with the insulin receptor. J. Biol. Chem. 2000, 275, 10093-10098. [CrossRef] [PubMed]

57. DiPilato, L.M.; Ahmad, F.; Harms, M.; Seale, P.; Manganiello, V.; Birnbaum, M.J. The Role of PDE3B Phosphorylation in the Inhibition of Lipolysis by Insulin. Mol. Cell. Biol. 2015, 35, 2752-2760. [CrossRef] [PubMed]

58. Odagiri, K.; Katoh, H.; Kawashima, H.; Tanaka, T.; Ohtani, H.; Saotome, M.; Urushida, T.; Satoh, H.; Hayashi, H. Local control of mitochondrial membrane potential, permeability transition pore and reactive oxygen species by calcium and calmodulin in rat ventricular myocytes. J. Mol. Cell. Cardiol. 2009, 46, 989-997. [CrossRef] [PubMed]

59. Kitamura, T.; Kitamura, Y.; Kuroda, S.; Hino, Y.; Ando, M.; Kotani, K.; Konishi, H.; Matsuzaki, H.; Kikkawa, U.; Ogawa, W.; et al. Insulin-induced phosphorylation and activation of cyclic nucleotide phosphodiesterase 3B by the serine-threonine kinase Akt. Mol. Cell. Biol. 1999, 19, 6286-6296. [CrossRef] [PubMed]

60. Onuma, H.; Osawa, H.; Ogura, T.; Tanabe, F.; Nishida, W.; Makino, H. A newly identified 50 kDa protein, which is associated with phosphodiesterase $3 \mathrm{~B}$, is phosphorylated by insulin in rat adipocytes. Biochem. Biophys. Res. Commun. 2005, 337, 976-982. [CrossRef] [PubMed]

61. Nilsson, R.; Ahmad, F.; Sward, K.; Andersson, U.; Weston, M.; Manganiello, V.; Degerman, E. Plasma membrane cyclic nucleotide phosphodiesterase 3B (PDE3B) is associated with caveolae in primary adipocytes. Cell Signal. 2006, 18, 1713-1721. [CrossRef] [PubMed]

62. Patrucco, E.; Notte, A.; Barberis, L.; Selvetella, G.; Maffei, A.; Brancaccio, M.; Marengo, S.; Russo, G.; Azzolino, O.; Rybalkin, S.D.; et al. PI3Kgamma modulates the cardiac response to chronic pressure overload by distinct kinase-dependent and -independent effects. Cell 2004, 118, 375-387. [CrossRef] [PubMed]

63. Perino, A.; Beretta, M.; Kilic, A.; Ghigo, A.; Carnevale, D.; Repetto, I.E.; Braccini, L.; Longo, D.; Liebig-Gonglach, M.; Zaglia, T.; et al. Combined inhibition of PI3Kbeta and PI3Kgamma reduces fat mass by enhancing alpha-MSH-dependent sympathetic drive. Sci. Signal. 2014, 7, ra110. [CrossRef] [PubMed]

64. Damilano, F.; Perino, A.; Hirsch, E. PI3K kinase and scaffold functions in heart. Ann. N. Y. Acad. Sci. 2010, 1188, 39-45. [CrossRef] [PubMed]

65. Oikawa, M.; Wu, M.; Lim, S.; Knight, W.E.; Miller, C.L.; Cai, Y.; Lu, Y.; Blaxall, B.C.; Takeishi, Y.; Abe, J.; et al. Cyclic nucleotide phosphodiesterase 3A1 protects the heart against ischemia-reperfusion injury. J. Mol. Cell. Cardiol. 2013, 64, 11-19. [CrossRef] [PubMed] 
66. Ding, B.; Abe, J.; Wei, H.; Xu, H.; Che, W.; Aizawa, T.; Liu, W.; Molina, C.A.; Sadoshima, J.; Blaxall, B.C.; et al. A positive feedback loop of phosphodiesterase 3 (PDE3) and inducible cAMP early repressor (ICER) leads to cardiomyocyte apoptosis. Proc. Natl. Acad. Sci. USA 2005, 102, 14771-14776. [CrossRef] [PubMed]

67. Ding, B.; Abe, J.; Wei, H.; Huang, Q.; Walsh, R.A.; Molina, C.A.; Zhao, A.; Sadoshima, J.; Blaxall, B.C.; Berk, B.C.; et al. Functional role of phosphodiesterase 3 in cardiomyocyte apoptosis: Implication in heart failure. Circulation 2005, 111, 2469-2476. [CrossRef] [PubMed]

68. Zoccarato, A.; Surdo, N.C.; Aronsen, J.M.; Fields, L.A.; Mancuso, L.; Dodoni, G.; Stangherlin, A.; Livie, C.; Jiang, H.; Sin, Y.Y.; et al. Cardiac Hypertrophy Is Inhibited by a Local Pool of cAMP Regulated by Phosphodiesterase 2. Circ. Res. 2015, 117, 707-719. [CrossRef] [PubMed]

69. Maass, P.G.; Aydin, A.; Luft, F.C.; Schachterle, C.; Weise, A.; Stricker, S.; Lindschau, C.; Vaegler, M.; Qadri, F.; Toka, H.R.; et al. PDE3A mutations cause autosomal dominant hypertension with brachydactyly. Nat. Genet. 2015, 47, 647-653. [CrossRef] [PubMed]

70. Boda, H.; Uchida, H.; Takaiso, N.; Ouchi, Y.; Fujita, N.; Kuno, A.; Hata, T.; Nagatani, A.; Funamoto, Y.; Miyata, M.; et al. A PDE3A mutation in familial hypertension and brachydactyly syndrome. J. Hum. Genet. 2016, 61, 701-703. [CrossRef] [PubMed]

71. Toka, O.; Tank, J.; Schachterle, C.; Aydin, A.; Maass, P.G.; Elitok, S.; Bartels-Klein, E.; Hollfinger, I.; Lindschau, C.; Mai, K.; et al. Clinical Effects of Phosphodiesterase 3A Mutations in Inherited Hypertension With Brachydactyly. Hypertension 2015, 66, 800-808. [CrossRef] [PubMed]

72. Bristow, M.R.; Ginsburg, R.; Minobe, W.; Cubicciotti, R.S.; Sageman, W.S.; Lurie, K.; Billingham, M.E.; Harrison, D.C.; Stinson, E.B. Decreased catecholamine sensitivity and beta-adrenergic-receptor density in failing human hearts. N. Engl. J. Med. 1982, 307, 205-211. [CrossRef] [PubMed]

73. Bristow, M.R.; Ginsburg, R.; Umans, V.; Fowler, M.; Minobe, W.; Rasmussen, R.; Zera, P.; Menlove, R.; Shah, P.; Jamieson, S.; et al. Beta 1- and beta 2-adrenergic-receptor subpopulations in nonfailing and failing human ventricular myocardium: Coupling of both receptor subtypes to muscle contraction and selective beta 1-receptor down-regulation in heart failure. Circ. Res. 1986, 59, 297-309. [CrossRef] [PubMed]

74. Ungerer, M.; Parruti, G.; Bohm, M.; Puzicha, M.; DeBlasi, A.; Erdmann, E.; Lohse, M.J. Expression of beta-arrestins and beta-adrenergic receptor kinases in the failing human heart. Circ. Res. 1994, 74, $206-213$. [CrossRef] [PubMed]

75. Ungerer, M.; Bohm, M.; Elce, J.S.; Erdmann, E.; Lohse, M.J. Altered expression of beta-adrenergic receptor kinase and beta 1-adrenergic receptors in the failing human heart. Circulation 1993, 87, 454-463. [CrossRef] [PubMed]

76. Neumann, J.; Schmitz, W.; Scholz, H.; von Meyerinck, L.; Doring, V.; Kalmar, P. Increase in myocardial Gi-proteins in heart failure. Lancet 1988, 2, 936-937. [CrossRef]

77. Feldman, A.M.; Cates, A.E.; Veazey, W.B.; Hershberger, R.E.; Bristow, M.R.; Baughman, K.L.; Baumgartner, W.A.; Van Dop, C. Increase of the 40,000-mol wt pertussis toxin substrate (G protein) in the failing human heart. J. Clin. Investig. 1988, 82, 189-197. [CrossRef] [PubMed]

78. Feldman, M.D.; Copelas, L.; Gwathmey, J.K.; Phillips, P.; Warren, S.E.; Schoen, F.J.; Grossman, W.; Morgan, J.P. Deficient production of cyclic AMP: Pharmacologic evidence of an important cause of contractile dysfunction in patients with end-stage heart failure. Circulation 1987, 75, 331-339. [CrossRef] [PubMed]

79. Danielsen, W.; v der Leyen, H.; Meyer, W.; Neumann, J.; Schmitz, W.; Scholz, H.; Starbatty, J.; Stein, B.; Doring, V.; Kalmar, P. Basal and isoprenaline-stimulated cAMP content in failing versus nonfailing human cardiac preparations. J. Cardiovasc. Pharmacol. 1989, 14, 171-173. [CrossRef] [PubMed]

80. Bohm, M.; Reiger, B.; Schwinger, R.H.; Erdmann, E. cAMP concentrations, cAMP dependent protein kinase activity, and phospholamban in non-failing and failing myocardium. Cardiovasc. Res. 1994, 28, 1713-1719. [CrossRef] [PubMed]

81. Beuckelmann, D.J.; Nabauer, M.; Erdmann, E. Intracellular calcium handling in isolated ventricular myocytes from patients with terminal heart failure. Circulation 1992, 85, 1046-1055. [CrossRef] [PubMed]

82. Baim, D.S.; McDowell, A.V.; Cherniles, J.; Monrad, E.S.; Parker, J.A.; Edelson, J.; Braunwald, E.; Grossman, W. Evaluation of a new bipyridine inotropic agent-Milrinone-In patients with severe congestive heart failure. N. Engl. J. Med. 1983, 309, 748-756. [CrossRef] [PubMed]

83. Benotti, J.R.; Grossman, W.; Braunwald, E.; Davolos, D.D.; Alousi, A.A. Hemodynamic assessment of amrinone. A new inotropic agent. N. Engl. J. Med. 1978, 299, 1373-1377. [CrossRef] [PubMed] 
84. Jaski, B.E.; Fifer, M.A.; Wright, R.F.; Braunwald, E.; Colucci, W.S. Positive inotropic and vasodilator actions of milrinone in patients with severe congestive heart failure. Dose-response relationships and comparison to nitroprusside. J. Clin. Investig. 1985, 75, 643-649. [CrossRef] [PubMed]

85. Sinoway, L.S.; Maskin, C.S.; Chadwick, B.; Forman, R.; Sonnenblick, E.H.; Le Jemtel, T.H. Long-term therapy with a new cardiotonic agent, WIN 47203: Drug-dependent improvement in cardiac performance and progression of the underlying disease. J. Am. Coll. Cardiol. 1983, 2, 327-331. [CrossRef]

86. Maskin, C.S.; Sinoway, L.; Chadwick, B.; Sonnenblick, E.H.; Le Jemtel, T.H. Sustained hemodynamic and clinical effects of a new cardiotonic agent, WIN 47203, in patients with severe congestive heart failure. Circulation 1983, 67, 1065-1070. [CrossRef] [PubMed]

87. Anderson, J.L. Hemodynamic and clinical benefits with intravenous milrinone in severe chronic heart failure: Results of a multicenter study in the United States. Am. Heart J. 1991, 121, 1956-1964. [CrossRef]

88. Monrad, E.S.; McKay, R.G.; Baim, D.S.; Colucci, W.S.; Fifer, M.A.; Heller, G.V.; Royal, H.D.; Grossman, W. Improvement in indexes of diastolic performance in patients with congestive heart failure treated with milrinone. Circulation 1984, 70, 1030-1037. [CrossRef] [PubMed]

89. Pande, R.L.; Hiatt, W.R.; Zhang, P.; Hittel, N.; Creager, M.A. A pooled analysis of the durability and predictors of treatment response of cilostazol in patients with intermittent claudication. Vasc. Med. 2010, 15, 181-188. [CrossRef] [PubMed]

90. Del Monte, F.; Lebeche, D.; Guerrero, J.L.; Tsuji, T.; Doye, A.A.; Gwathmey, J.K.; Hajjar, R.J. Abrogation of ventricular arrhythmias in a model of ischemia and reperfusion by targeting myocardial calcium cycling. Proc. Natl. Acad. Sci. USA 2004, 101, 5622-5627. [CrossRef] [PubMed]

91. Lyon, A.R.; Bannister, M.L.; Collins, T.; Pearce, E.; Sepehripour, A.H.; Dubb, S.S.; Garcia, E.; O'Gara, P.; Liang, L.; Kohlbrenner, E.; et al. SERCA2a gene transfer decreases sarcoplasmic reticulum calcium leak and reduces ventricular arrhythmias in a model of chronic heart failure. Circ. Arrhythm. Electrophysiol. 2011, 4, 362-372. [CrossRef] [PubMed]

92. Duan, L.M.; Yu, H.Y.; Li, Y.L.; Jia, C.J. Design and discovery of 2-(4-(1H-tetrazol-5-yl)-1H-pyrazol-1-yl)-4(4-phenyl)thiazole derivatives as cardiotonic agents via inhibition of PDE3. Bioorg. Med. Chem. 2015, 23, 6111-6117. [CrossRef] [PubMed]

93. Lygren, B.; Carlson, C.R.; Santamaria, K.; Lissandron, V.; McSorley, T.; Litzenberg, J.; Lorenz, D.; Wiesner, B.; Rosenthal, W.; Zaccolo, M.; et al. AKAP complex regulates $\mathrm{Ca}^{2+}$ re-uptake into heart sarcoplasmic reticulum. EMBO Rep. 2007, 8, 1061-1067. [CrossRef] [PubMed]

94. Wilson, L.S.; Baillie, G.S.; Pritchard, L.M.; Umana, B.; Terrin, A.; Zaccolo, M.; Houslay, M.D.; Maurice, D.H. A phosphodiesterase 3B-based signaling complex integrates exchange protein activated by cAMP 1 and phosphatidylinositol 3-kinase signals in human arterial endothelial cells. J. Biol. Chem. 2011, 286, 16285-16296. [CrossRef] [PubMed]

(C) 2018 by the authors. Licensee MDPI, Basel, Switzerland. This article is an open access article distributed under the terms and conditions of the Creative Commons Attribution (CC BY) license (http://creativecommons.org/licenses/by/4.0/). 